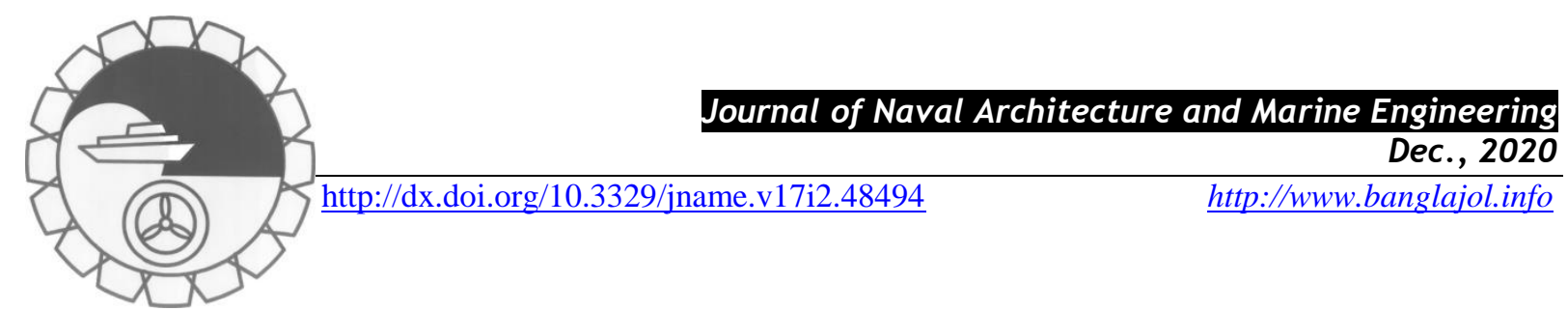

\title{
INFLUENCE OF THE TRANSOM IMMERSION ON SHIP RESISTANCE COMPONENTS AT LOW AND MEDIUM SPEEDS
}

I. Z. Mustaffa Kamal ${ }^{1}$, A. Imran Ismail ${ }^{2}$, M. Naim Abdullah ${ }^{3}$ and Y. Adnan Ahmed ${ }^{4}$

${ }^{1}$ Faculty of Maritime Engineering Technology, Universiti Kula-Lumpur, 32200 Lumut, Perak, iwanzamil@unikl.edu.my

${ }^{2}$ Malaysia Marine and Heavy Engineering Sdn. Bhd, Pasir Gudang, Johor, Malaysia, alifimran.i@mmhe.com.my

${ }^{3}$ Malaysia Marine and Heavy Engineering Sdn. Bhd, Pasir Gudang, Johor, Malaysia, naim.abdullah@mmhe.com.my

4*Faculty of Mechanical Engineering, Universiti Teknologi Malaysia, Johor Bahru, Malaysia, yaseen@ mail.fkm.utm.my

\begin{abstract}
:
The transom stern offered some advantages over the traditional rounded cruiser stern reducing the resistance of a ship. This can only be achieved if the transom stern is carefully designed with suitable transom immersion ratio. In this study, the influence of different transom area immersion ratios on the resistance components was investigated for a semidisplacement hull and a full displacement hull. The base hull was based on NPL hull form and KCS hull form for a semi-displacement and full-displacement hull respectively. The transom immersion ratios for the NPL hull were varied at a ratio of 0.5, 0.7, 0.8 and 1.0. The resistance of each of the NPL hull form was simulated at Froude number 0.3 up to 0.6. The transom immersion ratios for the KCS hull were varied at a ratio of 0.05, 0.1, 0.15 and 0.3. The resistance of each of the KCS hull form was simulated at Froude number 0.195, 0.23, 0.26 and 0.28. The transoms of both hulls were modified or varied systematically to study the influence of the transom shape or immersion on the total and wave resistance components. The investigation was carried out using a CFD software named SHIPFLOW 6.3 based on RANSE solver. These results on the NPL hull shows that the larger the transom immersion, the higher the resistance will be for a semi-displacement vessel. The increased resistance is contributed by additional frictional and wave resistance components. The results for the KCS hull seems to contradict with the results obtained from the NPL hull. The larger and deeper transom for the case of KCS hull form sometimes can be beneficial at higher Froude number.
\end{abstract}

Keywords: Transom stern, transom immersion, resistance components, low and medium speed

\section{Introduction}

In the modern era, the transom stern is now a feature that can be seen in most of the vessels such as merchant ships, high-speed ferries, enforcement patrol boat, naval frigates, corvettes etc. The transom stern offered some advantages over the traditional rounded cruiser stern with some possible drag reduction as reported by Maki (2005) and Kiss and Compton (1989). But with a poorly designed transom stern with high immersion ratio, the drag reduction will not be present, hence higher resistance will be observed. The high immersion ratio is normally are favourable to a waterjet propelled vessel. However, for a screw propelled vessel, having a high immersion ratio, will introduce a higher resistance. This drag penalty is not fully understood quantitatively.

Larsson and Raven (2010) presented the optimum values of the transom immersion ratio, $A_{T} / A_{X}$ where $A_{T}$ refers to the immersed transom area and $A_{X}$ is the immersed midship sectional area. These optimum values are for high-speed ships with Froude number from 0.35 to 1 . From the data presented, it was shown at high Froude number, a larger transom immersion ratio could be beneficial and do not produce drag penalty. Orych and Larsson (2015) explained the reason why transom should be larger for faster vessels. In their work, a planing hull designed by SSPA was selected. The shape of the waterlines and the buttocks were modified systematically to study the effect on the resistance components.

The effect of transom stern bottom profile form based on a displacement ship is studied by Yamato et al. (2003). Three model ships with different transom stern bottom profiles namely concave, flat and convex were tested in a 
towing tank. The resistance test shows that the concave bottom has the lowest resistance for the range of Froude number 2.3 to 3.2. However, beyond Froude number 3.2, the flat bottom profile has the lowest resistance. The effect of transom stern on the resistance components using NPL hull is studied by Sireli et al. (2000). Five monohull forms with different transom areas based on the NPL hull were investigated experimentally and numerically. The transom immersion ratio, $A_{T} / A_{X}$ were varied with ratios of $0.0,0.286,0.786$ and 1.0 . The total resistance was measured at Froude numbers from 0.2 to 1.0. From the experiment, the highest transom immersion ratio produced the highest resistance. Kiss and Compton (1989) studied the influence of the transom geometry on the resistance components. They used five transom shapes of a typical naval surface combatant to examine the effect of varied draft and beam on the resistance component. The study was performed using resistance tests in a towing tank and analytical studies using potential flow theory. The study concluded that a deeper and a wider transom increases the effective horsepower up to a 2 percent and a 3 percent, respectively. These increases in the effective horsepower are at Froude number larger than 0.38.

Duy et al. (2017) conducted an investigation on stern flow fields of a container ship hull with various transom configurations using CFD. The transom stern of an original container ship hull was modified in both breadth and height. The CFD method used a flow solver which solves the Reynolds Averaged Navier-Stokes (RANS) equations fpr incompressible flows. Duy et al. (2017) reported that the achieved results provide useful information for the practical optimization design of s tern shape of a ship hull. However, there is no clear conclusion on the best configuration at lower Froude number.

From the three studies mentioned above (Orych and Larsson, 2015, Sireli et al, 2000 and Kiss and Compton, 1989), it can be concluded that a larger transom at higher speed could be beneficial. At higher speeds, the deeper straighten buttock lines and waterlines create a high-pressure region at the aft, which produces a vertical lift. This vertical lift decreases the trim and sinkage at the aft, thus the wave resistance decrease (Allroth and $\mathrm{Wu}$, 2013). It should also be noted that at higher Froude number, ventilation occurs at the transom effectively extending the wave-making length of the vessel. In this condition, the transom runs dry, resulting in a hollow extending the wave-making length which will apparently cancel out the bow system wave and reduce the wave resistance component (Mustaffa Kamal, 2016). Among other researches on the transom ventilation are the work of Doctors et al (2007), Maki (2005), Yamano et al. (2003), Dea et al. (1981), Eslamdoost et al. (2015) and Haase et al. (2016). Since there is no clear conclusion at lower speeds, further study to examine the influence of the transom geometry at lower and medium speeds on the resistance components is necessary.

Two case studies were conducted in order to correlate the effect of a larger transom on the resistance components of a vessel; one is using a semi-displacement hull form and the other one is using a full displacement hull form. In the case of a semi-displacement hull form, the hull form of NPL series (Bailey, 1976) and in case of full-displacement hull form, the hull form of a 3,600 TEU container carrier, the KRISO Container ship or KCS were used. The transoms of both case studies were modified or varied systematically to study the influence of the transom shape or immersion on the total and wave resistance components. Therefore, the main objective of this present study is to quantitatively investigate the effect of the transom immersion on the ship's total resistance and the wave-making resistance.

\section{Mathematical Background}

The present CFD simulation is based on the finite volume Reynolds-Averaged Navier-Stokes (RANS) solver implemented by using SHIPFLOW. Solving the RANS equations gives the time average velocity and pressure. The time average of the Navier-Stokes equations used in the XCHAP solver can be expressed as (Broberg et al, 2007):

$$
\begin{aligned}
& \overline{\rho \frac{\partial U_{i}}{\partial t}}+\rho \frac{\partial\left(U_{j} U_{i}\right)}{\partial x_{j}}-\overline{\rho R_{i}}+\frac{\overline{\partial P}}{\partial x_{i}}-\overline{\frac{\partial}{\partial x_{j}}\left(\mu\left(\frac{\partial U_{i}}{\partial x_{j}}+\frac{\partial U_{j}}{\partial x_{i}}\right)\right)} \\
& =\rho \frac{\partial \overline{U_{i}}}{\partial t}+\rho \frac{\left(\overline{U_{j} U_{i}}\right)}{\partial x_{j}}-\rho \overline{R_{i}}+\frac{\partial \bar{P}}{\partial x_{i}}-\frac{\partial}{\partial x_{j}}\left(\mu\left(\frac{\partial \overline{U_{i}}}{\partial x_{j}}+\frac{\partial \overline{U_{j}}}{\partial x_{i}}\right)\right)
\end{aligned}
$$




$$
=\rho \frac{\partial u_{i}}{\partial t}+\rho \frac{\partial\left(u_{j} u_{i}+\overline{u_{j}^{\prime \prime} u_{i}^{\prime \prime}}\right)}{\partial x_{j}}-\rho \overline{R_{i}}+\frac{\partial p}{\partial x_{i}}-\frac{\partial}{\partial x_{j}}\left(\mu\left(\frac{\partial u_{i}}{\partial x_{j}}+\frac{\partial u_{j}}{\partial x_{i}}\right)\right)
$$

where $\rho$ is the density of fluid, $U_{i}$ and $U_{j}$ are the instantaneous velocity components in the Cartesian directions, $u_{i}$ and $u_{j}$ are time average velocity components in Cartesian coordinates, $\overline{U_{i}}, u_{i}^{\prime \prime}$ and $u_{j}^{\prime \prime}$ are the fluctuating velocity components in the Cartesian directions, $x_{i}$ and $x_{j}$ are the Cartesian coordinates, $R_{i}$ is the volume force, $P$ is the instantaneous pressure, $t$ is the time, and $\mu$ is the dynamic viscosity. The time averaged continuity equation and the Navier-Stokes equations for incompressible flow can be written as in Equation 2 and Equation 3 (Broberg et al, 2007).

$$
\begin{gathered}
\frac{\partial u_{i}}{\partial x_{i}}=0 \\
\frac{\partial u_{i}}{\partial t}+\frac{\partial\left(u_{j} u_{i}+\overline{u_{j}^{\prime \prime} u_{i}^{\prime \prime}}\right)}{\partial x_{j}}=\overline{R_{i}}-\frac{1}{\rho} \frac{\partial p}{\partial x_{i}}+\frac{\partial}{\partial x_{j}}\left(v\left(\frac{\partial u_{i}}{\partial x_{j}}+\frac{\partial u_{j}}{\partial x_{i}}\right)\right)
\end{gathered}
$$

where $v$ is the kinematic viscosity, and $v=\mu / \rho$. More equations are needed in order to solve the system due to the Reynolds stresses $-\rho \overline{u_{i} u_{j}^{\prime \prime}}$. The Boussinesq approximation is used for incompressible flows as in Equation 4 (Broberg et al, 2007).

$$
\rho \overline{u_{i}^{\prime \prime} u_{j}^{\prime \prime}}=-\mu_{T}\left(\frac{\partial u_{i}}{\partial x_{j}}+\frac{\partial u_{j}}{\partial x_{i}}\right)+\frac{2}{3} \rho k \delta_{i j}
$$

where $\mu_{T}$ is the turbulent dynamic viscosity and $\mathrm{k}$ is the turbulent kinetic energy. Thus, the Reynolds-averaged equations can be written as in Equation 5 (Broberg et al, 2007).

\section{Case Studies}

$$
\frac{\partial u_{i}}{\partial t}+\frac{\partial\left(u_{j} u_{i}\right)}{\partial x_{j}}=\overline{R_{i}}-\frac{1}{\rho} \frac{\partial p}{\partial x_{i}}-\frac{2}{3} \frac{\partial k}{\partial x_{i}}+\frac{\partial}{\partial x_{j}}\left(v_{E}\left(\frac{\partial u_{i}}{\partial x_{j}}+\frac{\partial u_{j}}{\partial x_{i}}\right)\right)
$$

\subsection{Analysis using NPL and KCS hull form}

As mentioned earlier in the introduction, two case studies were conducted; one is using a semi-displacement hull form and the other one is using a full displacement hull form. In the case study of a semi-displacement hull form, the hull form of NPL series (Bailey, 1976) was used. The particulars of the NPL are listed in Table 1, where this NPL hull is a typical round bilge hull with straight entrance waterlines, rounded after-body section and straight buttock lines terminating sharply at the transom. This hull form was chosen for the case study because of the availability of an extensive amount of experimental results of total, residuary and wave resistance coefficient (Bailey, 1976).

Table 1: Ship particulars of the NPL hull (Bailey, 1976)

\begin{tabular}{|l|l|l|l|l|}
\hline Ship Particulars & Symbol & Unit & Ship & Model \\
\hline Length overall & $L_{O A}$ & $\mathrm{~m}$ & 38 & 2.758 \\
\hline Length on waterline & $L_{W L}$ & $\mathrm{~m}$ & 35 & 2.540 \\
\hline Breadth & $B$ & $\mathrm{~m}$ & 6 & 0.435 \\
\hline Draught & $T$ & $\mathrm{~m}$ & 2.223 & 0.161 \\
\hline Displacement & $\nabla$ & $\mathrm{m}^{3}$ & 155.73 & 0.0595 \\
\hline Block Coefficient & $C_{B}$ & - & 0.397 & 0.397 \\
\hline Midship coefficient & $C_{M}$ & - & 0.656 & 0.656 \\
\hline Scale Ratio & $\lambda$ & - & 1 & 13.78 \\
\hline
\end{tabular}


In this case study, the transom immersion ratio, $A_{T} / A_{X}$ was varied into four cases. The original transom immersion ratio was at 0.5 . The transom immersion ratios were varied to a ratio of $0.7,0.8$ and 1.0 as shown in Fig. 1.
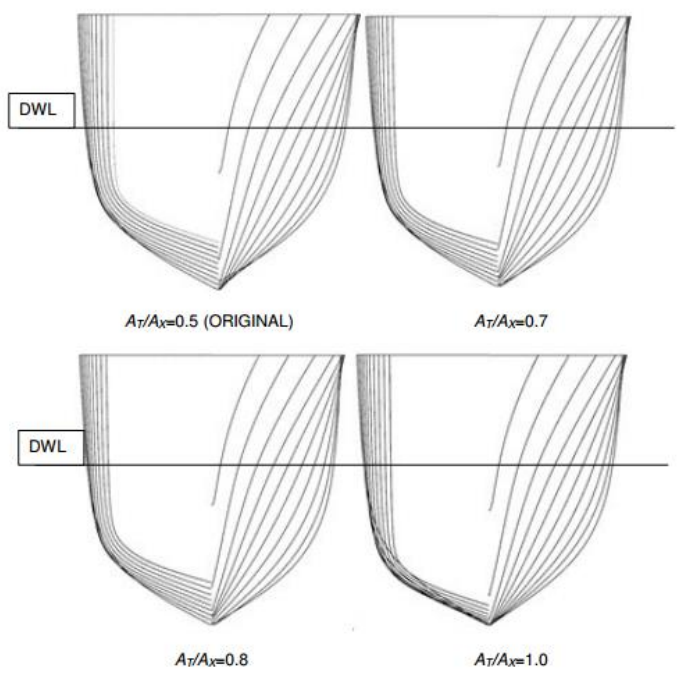

Fig. 1: NPL hull with varied transom immersion ratios of $0.5,0.7,0.8$, and 1.0 .

In the second case study using a full-displacement hull form, the hull form of a 3,600 TEU container carrier named KRISO Container Ship (KCS) was chosen. The experimental results of the KCS hull are published by Van et al. (1997) and Fujisawa et al. (2000). The particulars of the KCS are listed in Table 2. The KCS hull is a modern commercial hull form with a bulbous bow and a stern bulb. The hull form will resemble closely to those of the commercial ships used nowadays. The KCS has a low block coefficient and a moderate speed.

Table 2: Ship particulars of the KCS hull (Van et al, 1997) and (Fujisawa et al, 2000)

\begin{tabular}{|l|l|l|l|l|}
\hline Ship Particulars & Symbol & Unit & Ship & Model \\
\hline Length perpendiculars & $L_{P P}$ & $\mathrm{~m}$ & 230 & 6.371 \\
\hline Length on waterline & $L_{W L}$ & $\mathrm{~m}$ & 232.5 & 6.440 \\
\hline Breadth & $B$ & $\mathrm{~m}$ & 32.2 & 0.892 \\
\hline Draught & $T$ & $\mathrm{~m}$ & 10.8 & 0.299 \\
\hline Displacement & $\nabla$ & $\mathrm{m}^{3}$ & 52030 & 1.106 \\
\hline Block Coefficient & $C_{B}$ & - & 0.651 & 0.651 \\
\hline Midship coefficient & $C_{M}$ & - & 0.985 & 0.985 \\
\hline Scale Ratio & $\lambda$ & - & - & 36.1 \\
\hline
\end{tabular}

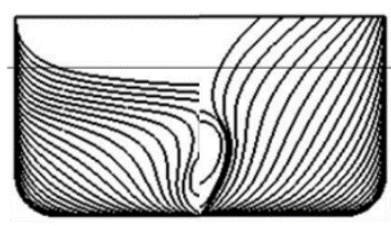

$A_{T} / A_{X}=0.05$

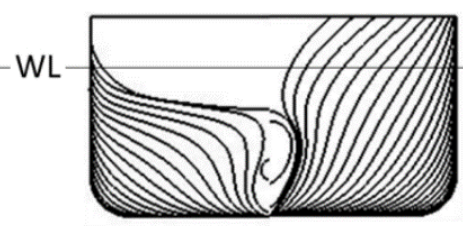

$A_{T} / A_{X}=0.1$

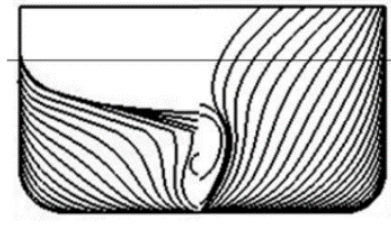

$A_{T} / A_{x}=0.15$

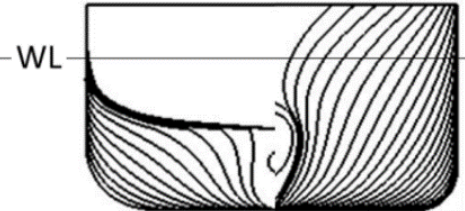

$A_{T} / A_{X}=0.3$

Fig. 2: KCS hull with varied transom immersion ratios of $0.05,0.1,0.15$, and 0.3 . 
In the case study using the KCS hull form, the transom immersion ratio, $A_{T} / A_{X}$ was varied into four cases. The original transom immersion ratio was at 0.05 . The transom immersion ratios were varied to a ratio of $0.05,0.1$, 0.15 and 0.3 as shown in Fig. 2. Both hulls with the different transom immersion ratio were modelled in such a way so that the effects of the buttock curvature to the overall results were minimized. In doing so, there are no significant changes in the $L C B, C_{M}$ and $C_{B}$.

\subsection{CFD computations using XCHAP (RANSE solver)}

The investigation was conducted using a CFD code SHIPFLOW 6.3 which is available from FLOWTECH International AB (Broberg et al, 2007). The solver used in the SHIPFLOW code is a viscous flow RANSE solver XCHAP. XCHAP is a steady-state finite volume solver. The turbulence was modelled using the Explicit Algebraic Stress Model (EASM). A global approach was chosen for the computation where the computational domain was built using structured grids.

\subsection{The CFD Simulations Condition}

All the grids in this study were created using the SHIPFLOW in-house grid generation module XGRID for the port side of the hull only, as it is assumed that the flow around the hull is symmetry. Finer grids were selected at the bow and the aft area, as to accurately captured the boundary layer flow at the bow and the flow separation at the aft region as shown in Fig. 3. There is no wall function used in the computational setup as the grids were increased in its density closer to the hull.

The free surface of the water was modelled using panel method which is available in the XPAN module in SHIPFLOW. The wet transom treatment was applied to the aft of the vessels in both case study using the WTRAN configuration in SHIPFLOW. A global approach was chosen in the simulation set-up where the grid or the computational domain starts at a specific distance at upstream and ending at a specific distance downstream of the ship. This is a recent update by FLOWTECH in their Shipflow version 6, where previously only zonal approach was available in the older version. More details in the computation using zonal approach can be found in Broberg and Orych (2019) and Karim and Naz (2019). The global approach is illustrated in Fig. 3, where the grids starts at upstream and ending downstream of the ship.

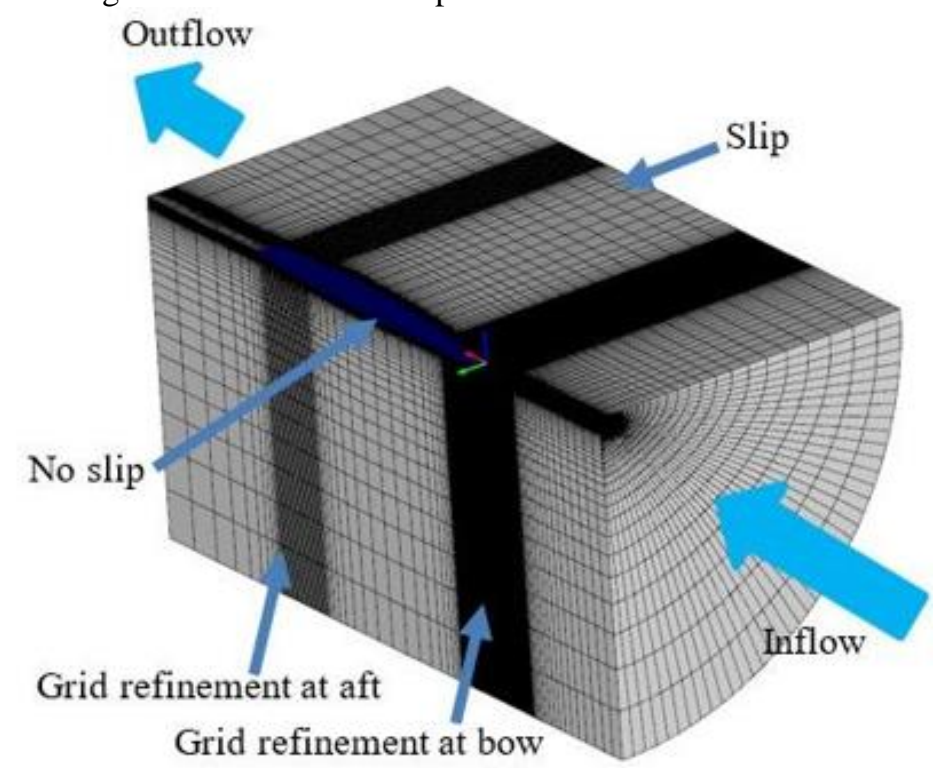

Fig. 3: The computational domain used the H-O grid topology, with the inflow and outflow of the viscous flow computation shown above. No slip condition was applied to the boundary region close to the hull.

The viscous flow computations using XCHAP were carried out with the computational domain having six boundaries as shown in Fig. 3. The distance between the inlet of the viscous flow and the fore-perpendicular of the ship is at half the length perpendiculars, $L_{P P}$ of the ship. The outlet of the viscous flow is located at 1.5 of length perpendiculars, $L_{P P}$ of the ship behind the aft-perpendicular of the ship. The radius of the cylindrical 
outer boundary is at 1.0 length perpendiculars of the ship, as listed in Table 3 . This is necessary to prevent from any influence of the blockage effect due to shallow depth of the domain boundary.

Table 3: The computational domain boundary distances

\begin{tabular}{|l|l|}
\hline Boundaries & Distance \\
\hline Inlet of the domain & $0.5 \mathrm{~L}$ from FP \\
\hline Outlet of the domain & $1.5 \mathrm{~L}$ from AP \\
\hline Radius of the domain & 1.0 from keel \\
\hline
\end{tabular}

Both case-studies were validated against experimental data. For the NPL case study, the computed results of bare hull resistance were validated against experimental data which can be found in Bailey (1976). For the KCS case study, the computed results of bare hull resistance were validated against experimental data which can be found in Van et al (1997). Both computed results show a close agreement with the experimental results.

\section{4 Grid independence study}

A grid independence study was performed in order to define the optimum number of grid cells to be used in the CFD simulations. The study was done using the results of total resistance coefficients of the NPL's bare hull and the KCS bare hull as the main criterion in the study. The number of grid cells chosen for the CFD simulation for the NPL case study is at 2.3 million grid cells. It was found that at 2.3 million grid cells the result of the total resistance coefficient $C_{T}$ will be independent to the number of cells as shown in Figure 4(a), shown here for the NPL case study. The number of grid cells chosen for the CFD simulation for the NPL case study is at 2.6 million grid cells. It was found that at 2.6 million grid cells the result of the total resistance coefficient $C_{T}$ will be independent to the number of cells as shown in Figure 4(b), shown here for the KCS case study.

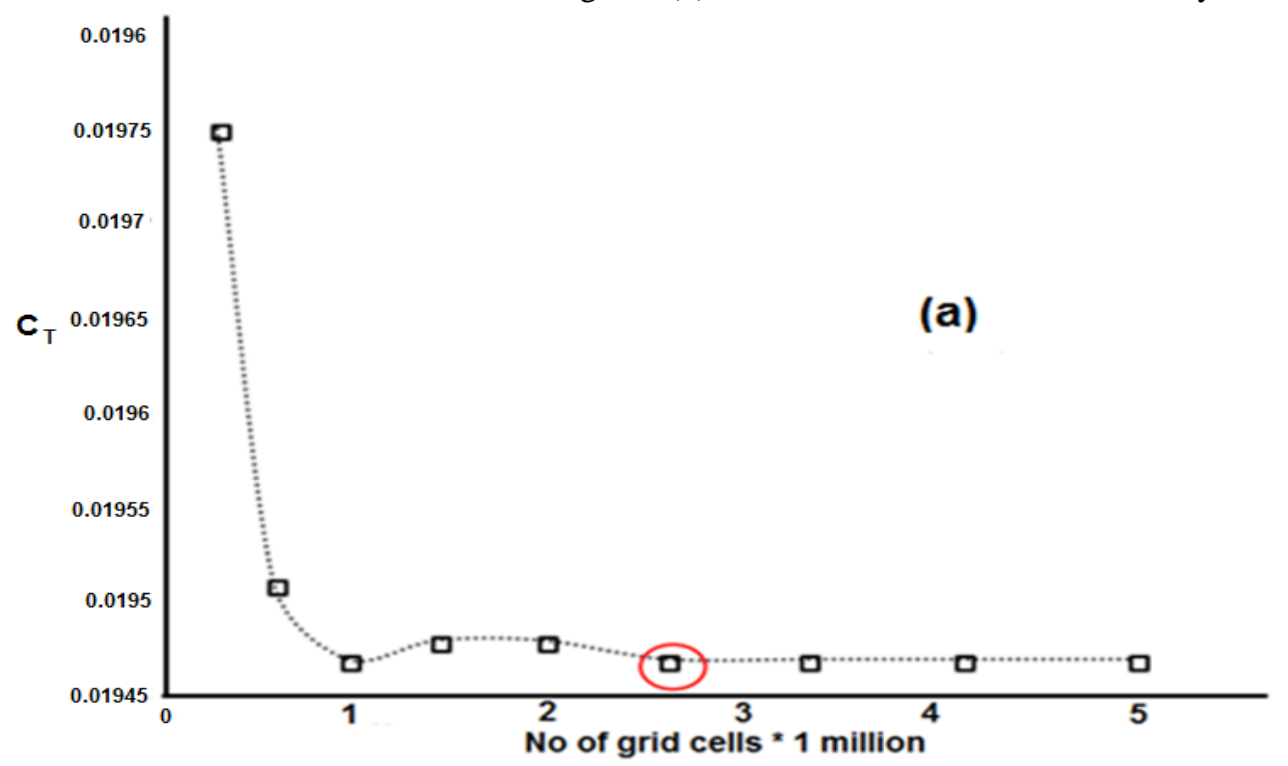

Fig. 4(a): The dependency of the total resistance coefficient to the grid cells number for the NPL case study

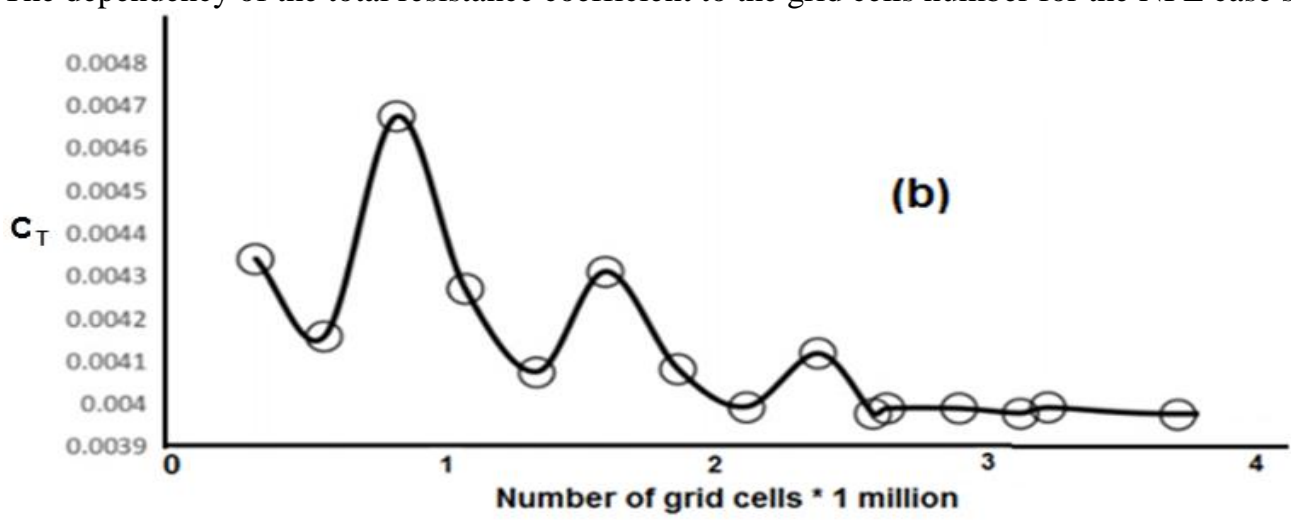

4(b): The dependency of the total resistance coefficient to the grid cells number for the KCS case study 
Fine grid settings were emphasized at the forward and at the mid-ship region of the NPL's hull in order to capture the higher pressure gradient at the bow and at the aft region. A similar setting was done to the KCS computation setup. With fine grid settings emphasized at the bow and the aft region in order to capture the higher pressure gradient at these regions.

\section{Results and Discussions}

4.1 The case study using NPL hull form

The total resistance at various transom immersion ratios was simulated using similar grid configurations for all four variations of transom immersion on the NPL hull form. The resistance of each of the NPL hull form was simulated at Froude numbers of 0.3, 0.4, 0.5 and 0.6. In Fig. 5, the results are presented as the total resistance, $R_{T}$ with respect to the Froude number $F_{R}$. The NPL hull with the transom immersion ratio of 1 has a higher total resistance when compared to the hull with transom immersion ratio of $0.5,0.7$ and 0.8 . The NPL hull with transom immersion ratio of 0.5 has the lowest total resistance.

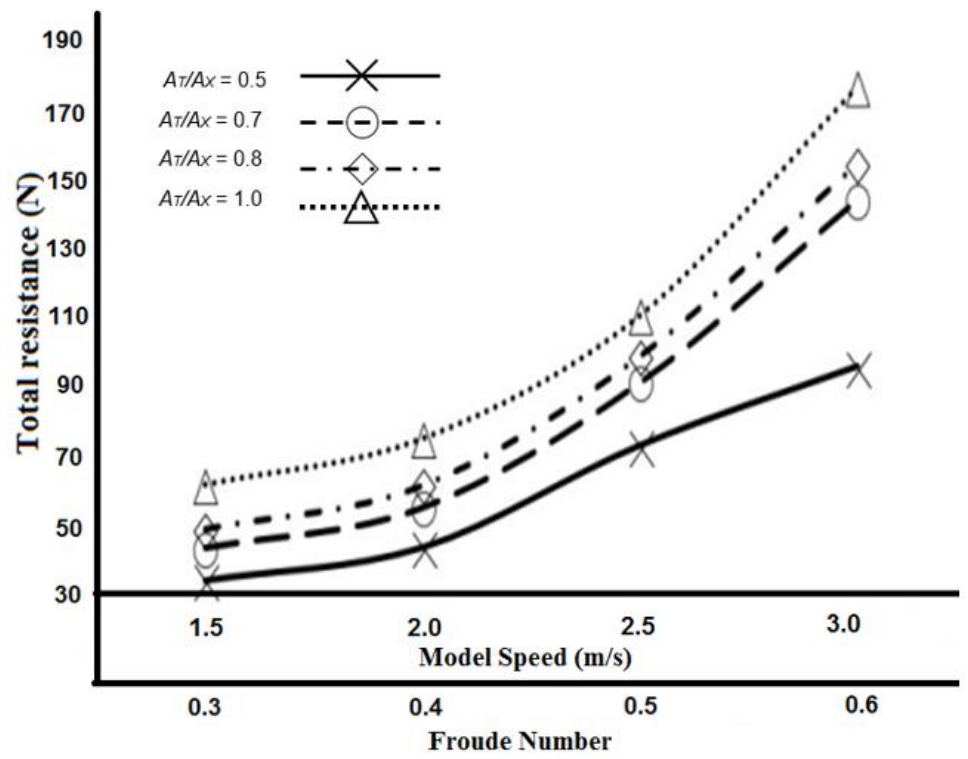

Fig. 5: The total resistance of the NPL hull at different transom immersion.

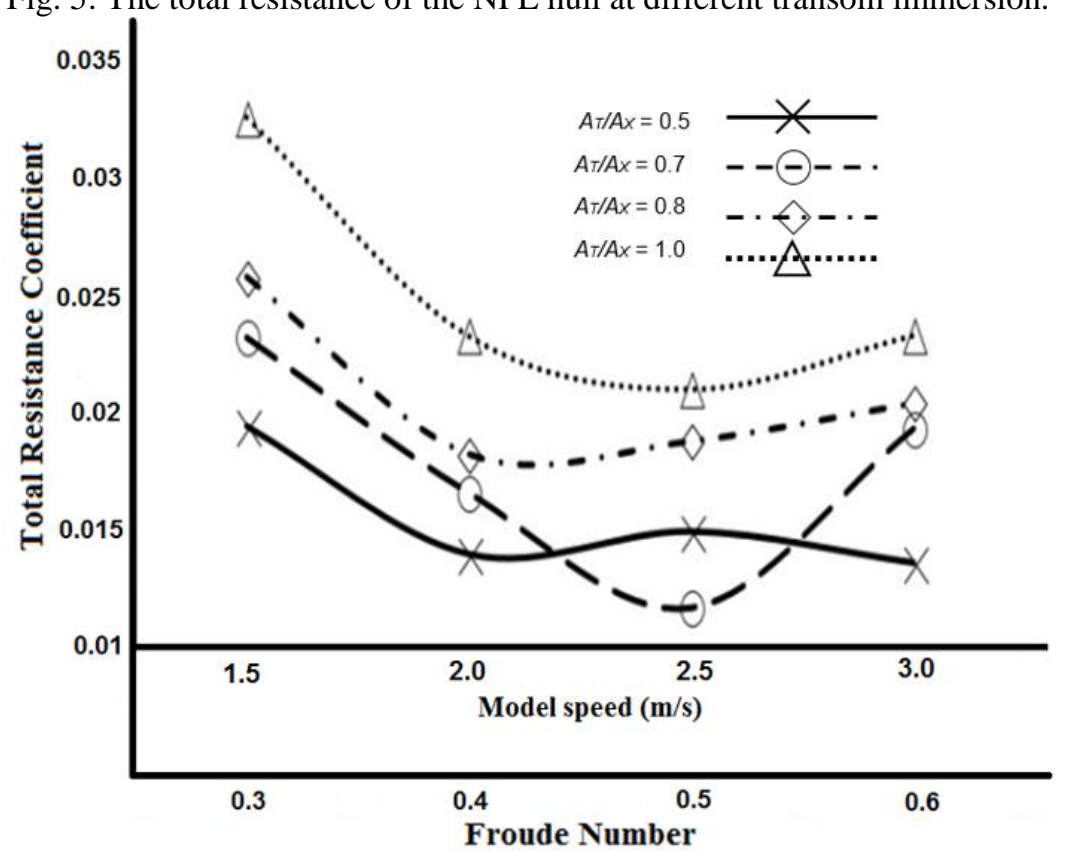

Fig. 6: The total resistance coefficient of the NPL hull at different transom immersion. 
The results were also compared in terms of its total resistance coefficient, $C_{T}$ as shown in Fig. 6 . In this figure, the total resistance coefficients for various transom immersion ratios are plotted with respect to the Froude number. The NPL hull with the transom immersion ratio of 0.5 has a lower total resistance coefficient when compared to the hull with transom immersion ratio of 0.5, 0.7 and 0.8. But at Froude number 0.5, the hull with the transom immersion of 0.7 has a lower total resistance coefficient than the total resistance coefficient of the hull with transom immersion of 0.5 .

At this Froude number of 0.5, the NPL hull with the transom immersion 0.5 experienced a drag hump and the NPL hull with the transom immersion 0.7 experienced a drag hollow as observed in Fig. 6 . The reason behind this unusual behavior of the curve is still unknown to the authors and needs further study for correct explanation. The results are also compared in terms of its wave resistance, $R_{W}$. The wave resistance is plotted with respect to the Froude number as shown in Fig. 7. The NPL hull with the transom immersion ratio of 0.5 has a lower wave resistance when compared to the hull with transom immersion ratios of $0.5,0.7$ and 0.8 .

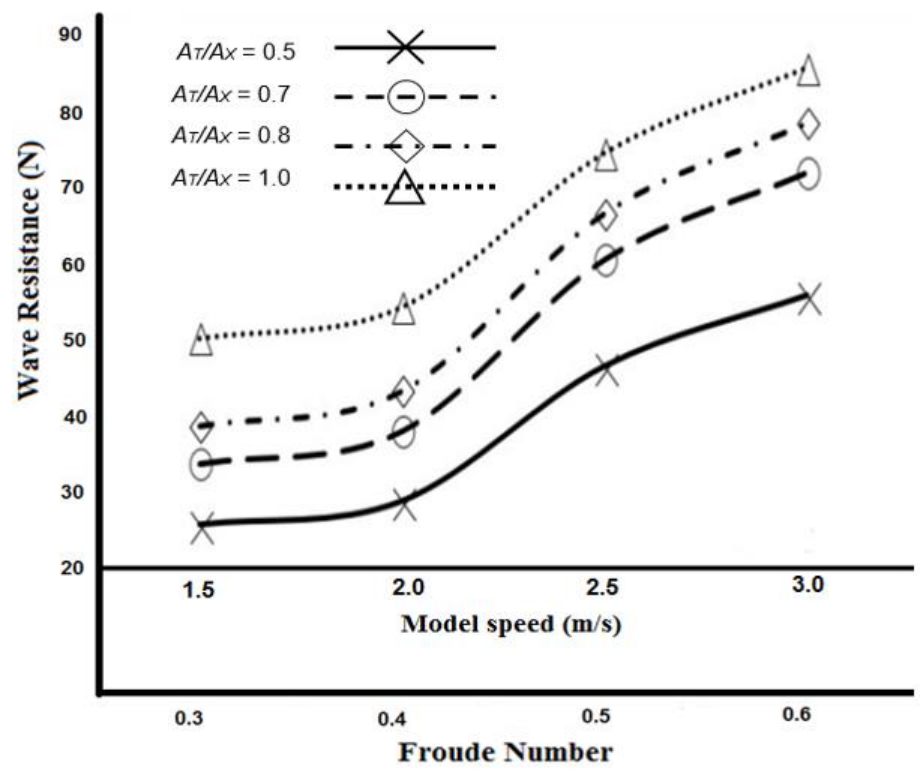

Fig. 7: The wave resistance of the NPL hull at different transom immersion ratio.

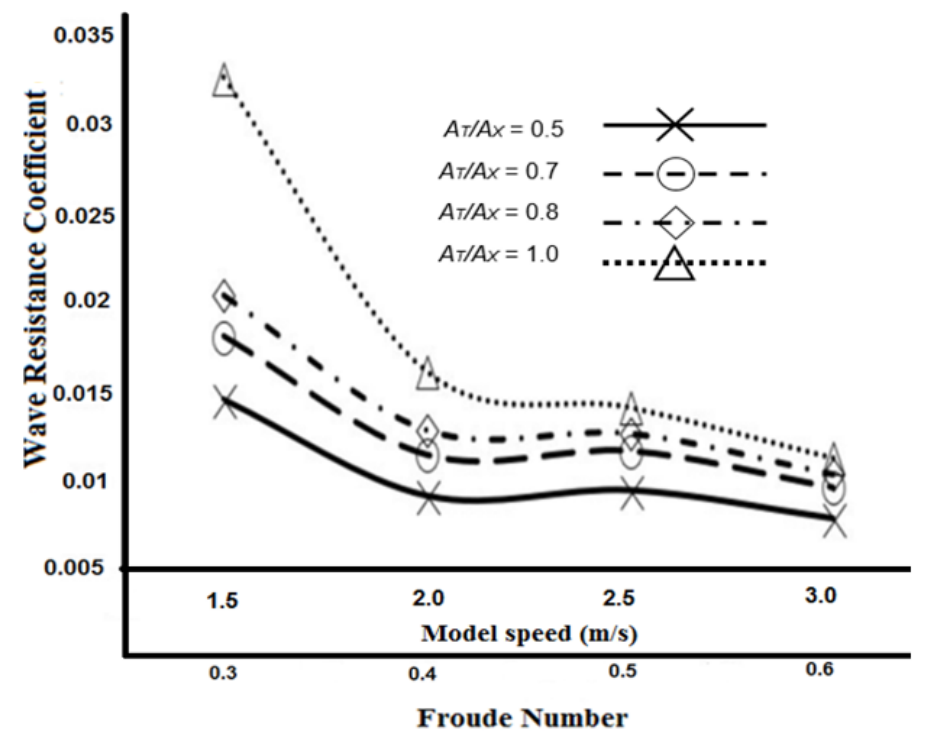

Fig. 8: The wave resistance coefficient of the NPL hull at different transom immersion ratio. 
In Fig. 8, the wave resistance coefficient is compared at different transom immersion ratios. The NPL hull with the transom immersion ratio of 0.5 as expected has a lower wave resistance coefficient when compared to the hull with transom immersion ratios of $0.5,0.7$ and 0.8 .

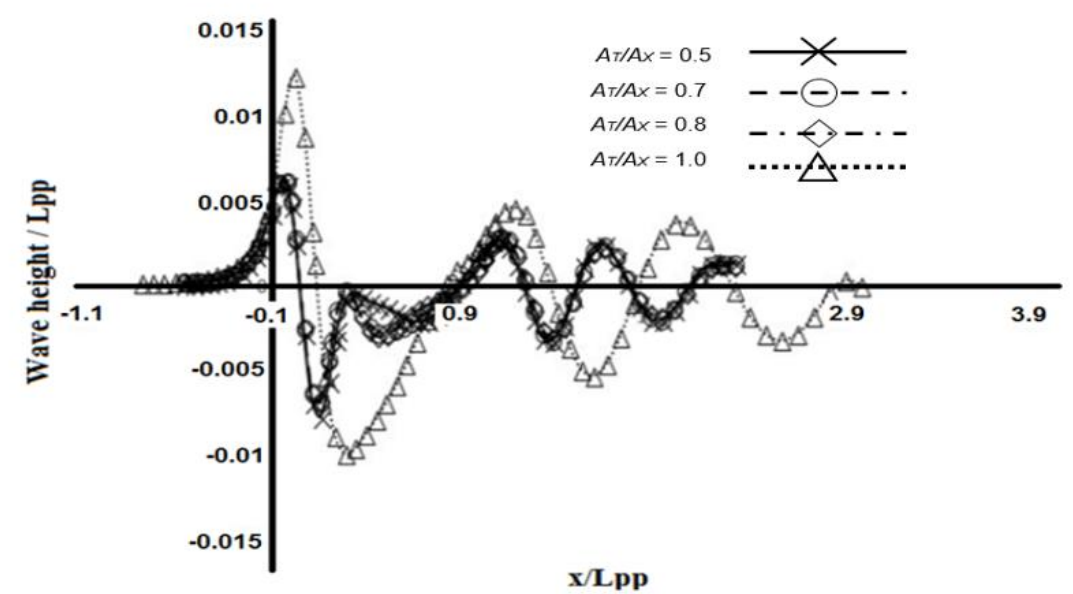

Fig. 9: The wave height/ $L_{P P}$ at different transom immersion ratio for the NPL hull at Froude number 0.3

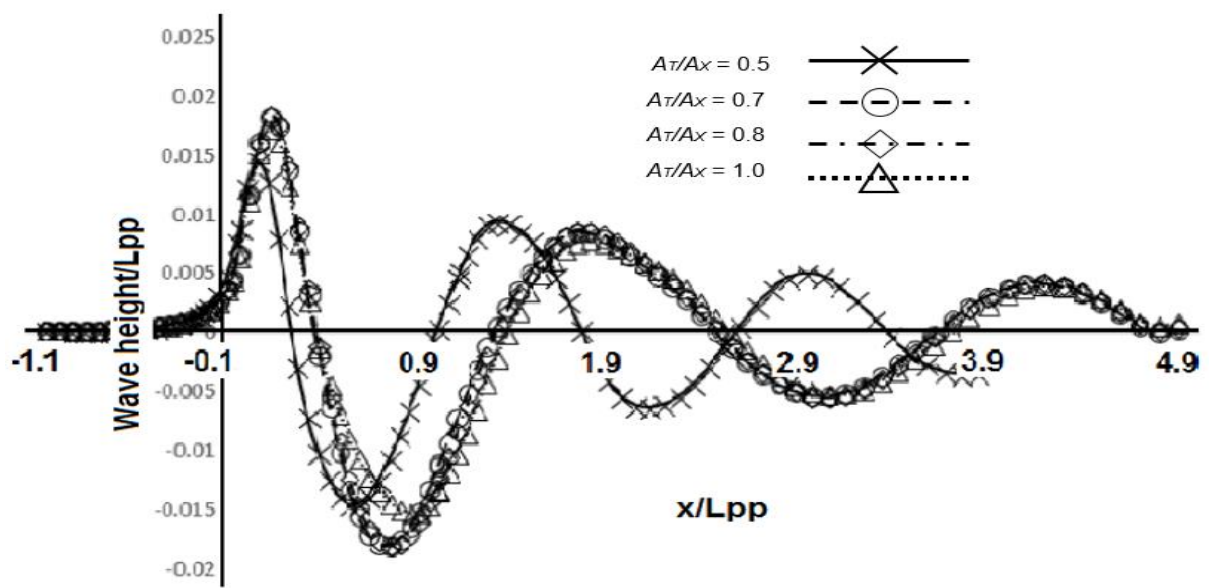

Fig. 10: The wave height/ $L_{P P}$ at different transom immersion ratio for the NPL hull at Froude number 0.5

The wave-cut profiles were also compared in the NPL case study at Froude numbers 0.3 and 0.5 . All the wavecut profiles were taken at $Y / L_{p p}=0.1$. It can be seen clearly in Figs. 9 and 10 that the wave height $/ L_{P P}$ for the transom immersion ratio of 1 has the highest peak and the deepest trough compared to the wave height/ $L_{P P}$ for transom immersion ratios of $0.5,0.7$ and 0.8 . There is a significant increase of wave height at the bow region for the NPL hull with transom immersion ratio of 1.0 as a result of higher pressure gradient at the bow compared to those with the rest of the transom immersion ratios.

In Figs. 11, 12, 13, 14, 15, 16, 17 and 18, the wave elevation contours for all transom immersion ratios at Froude number $0.3,0.4,0.5$ and 0.6 are shown. It can be observed that the low-pressure region at midship where the lowest elevation of the free surface exists, increases with the increase in the transom immersion ratio. The stern wave system is prominent with the increase in the transom immersion ratio. It is also observed with the increase in Froude number, the low-pressure region at midship, somehow moves to the stern thus creating low pressure at the stern which increases the dynamic trim and sinkage. This increase in dynamic trim and sinkage results with an increase in the viscous resistance. As mentioned earlier, an increase in hydrodynamic pressure at the aft would be beneficial in reducing the resistance components, where the higher hydrodynamic pressure increases the vertical lift that reduces the dynamic trim and sinkage. These results proved that the larger the transom immersion, the higher the resistance will be for a semi-displacement vessel such as the NPL hull. The increased resistance is contributed by additional frictional and wave resistance components. As the transom immersion ratio increases, the wetted surface area also increases thereby resulting in the higher frictional resistance. The increase in the transom immersion also creates a larger stern wave system which increases the wave resistance. 
But in Figs. 13 and 14, the wave elevation contour at Froude number 0.4 for transom immersion ratio 0.7 seems to be higher than the wave elevation contour for transom immersion ratios 0.8 and 1.0. Further investigation is needed to check this unusual behavior.

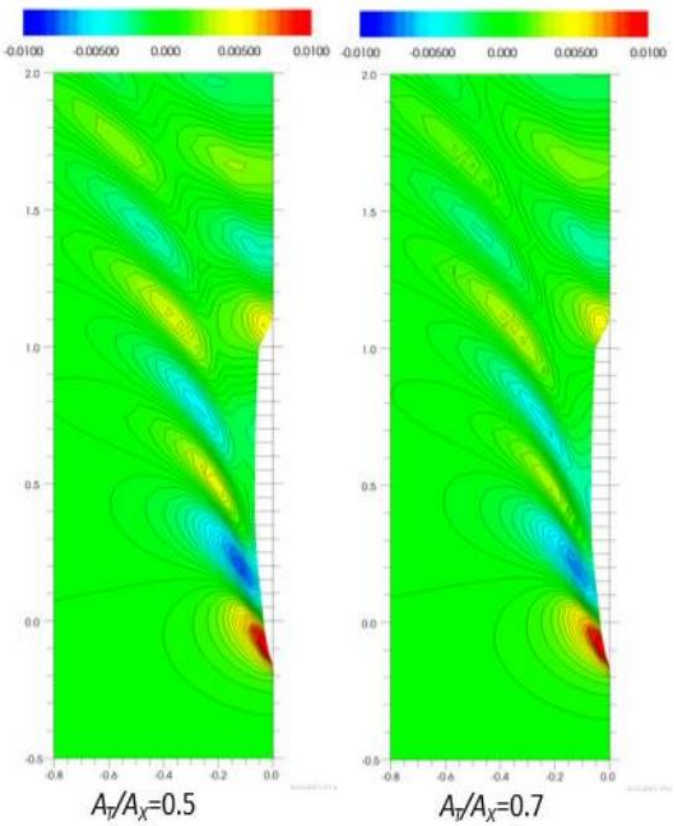

Fig. 11: The wave elevation contours for the NPL case study for transom immersion ratio 0.5 and 0.7 at Froude number 0.3
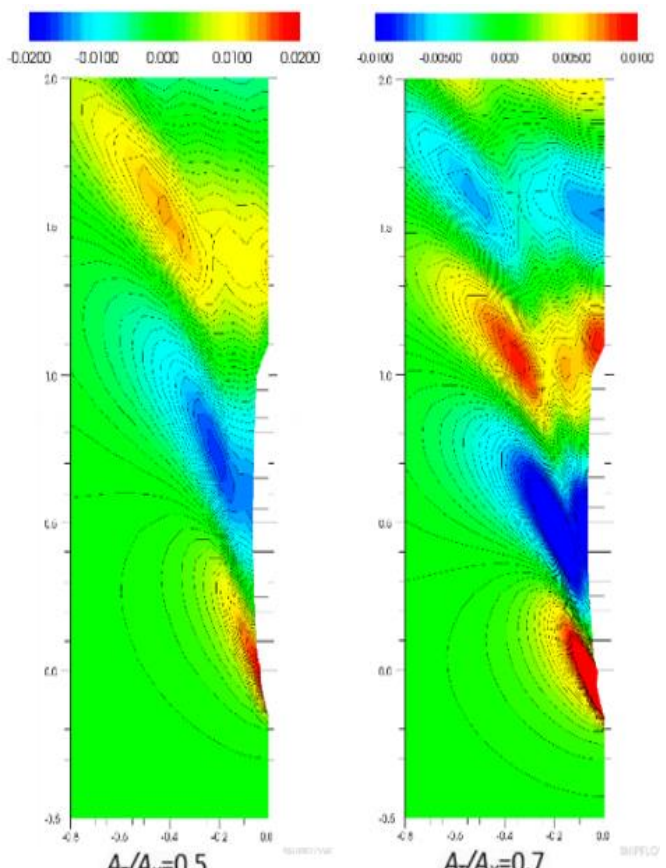

Fig. 13. The wave elevation contours the NPL case study for transom immersion ratio 0.5 and 0.7 at Froude number 0.4

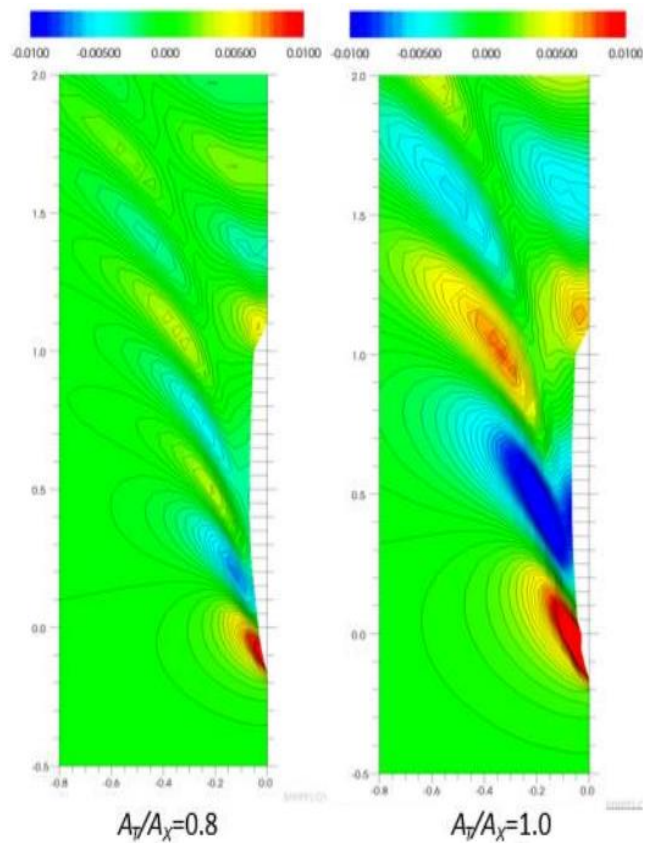

Fig. 12: The wave elevation contours for the NPL case study for transom immersion ratio 0.8 and 1.0 at Froude number 0.3
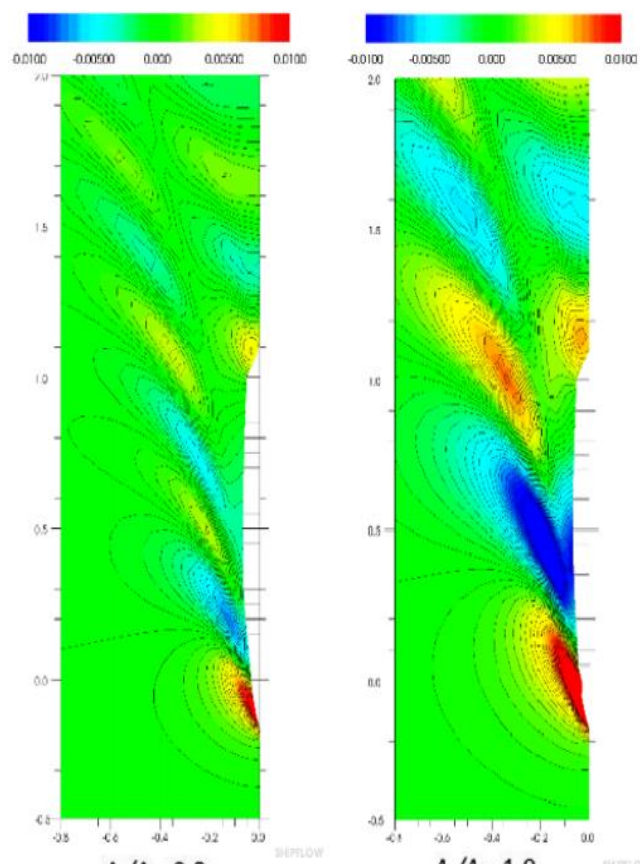

$A_{\text {T⿰亻 }} / A_{X}=1.0$

Fig. 14. The wave elevation contours for the NPL case study for transom immersion ratio 0.8 and 1.0 at Froude number 0.4 

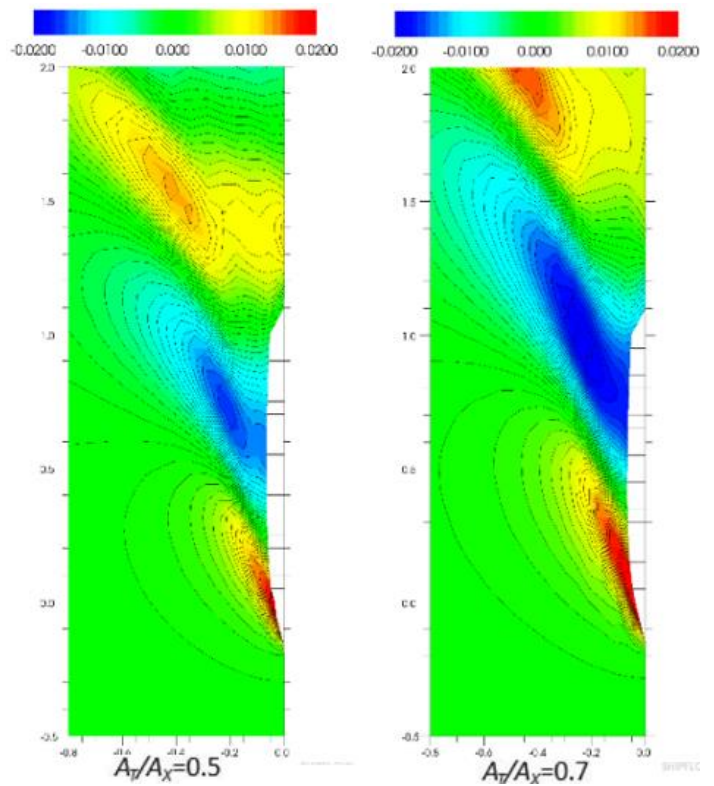

Fig. 15: The wave elevation contours for the NPL case study for transom immersion ratio 0.5 and 0.7 at Froude number 0.5
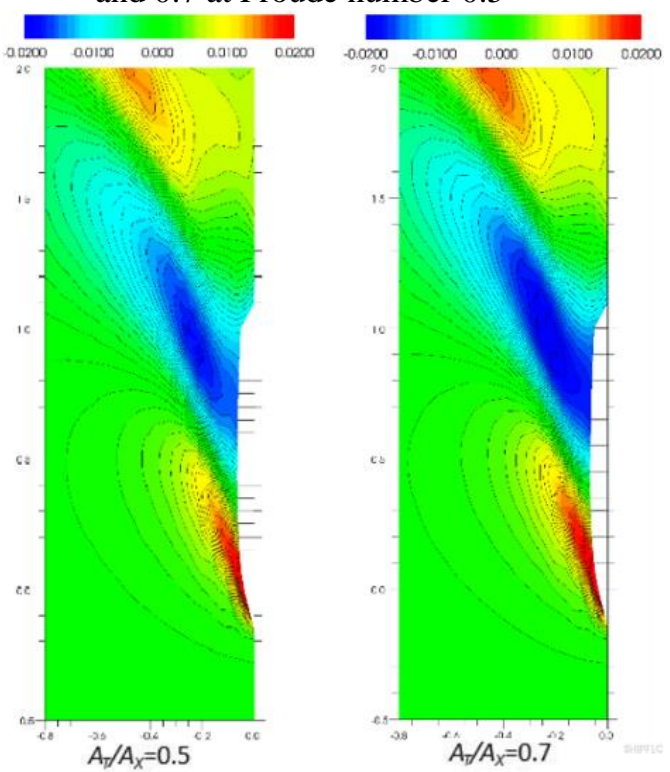

Fig. 17. The wave elevation contours for the NPL case study for transom immersion ratio 0.5 and 0.7 at Froude number 0.6

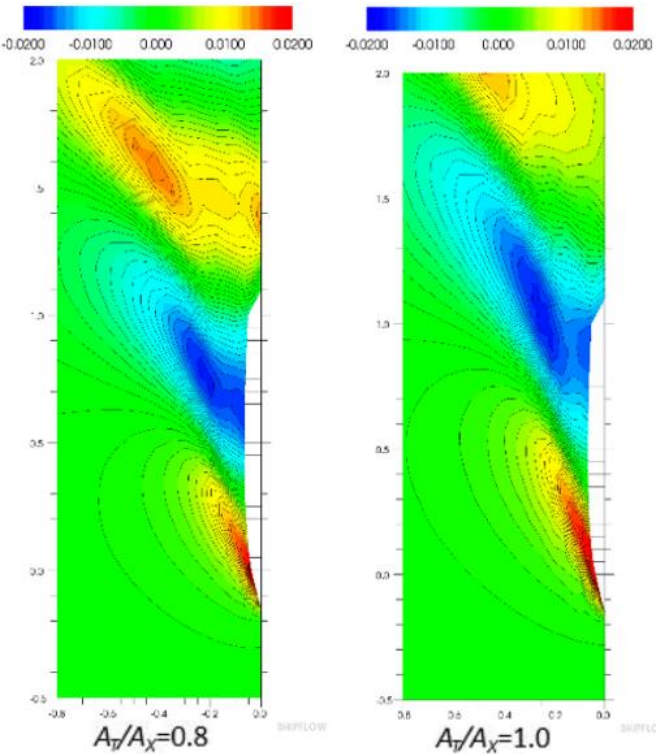

Fig. 16: The wave elevation contours for the NPL case study for transom immersion ratio 0.8 and 1.0 at Froude number 0.5
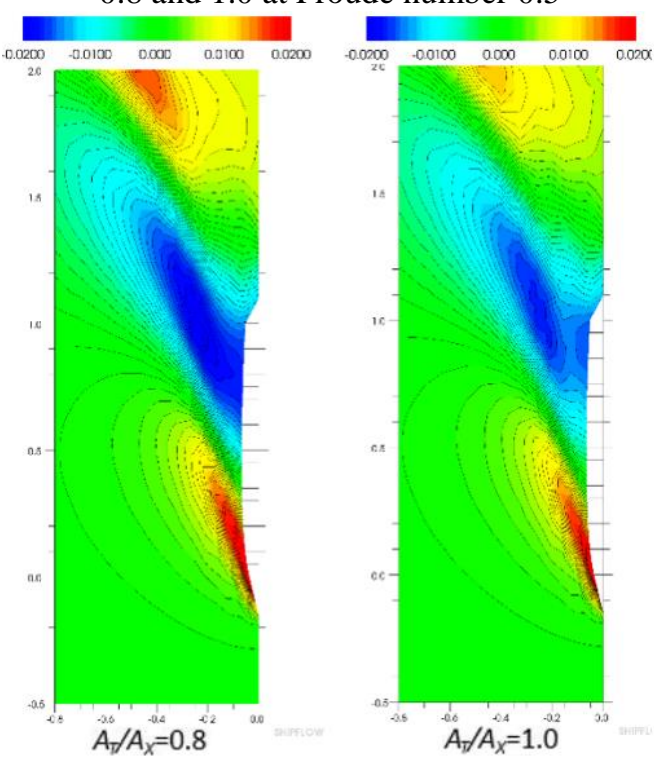

Fig. 18: The wave elevation contours for the NPL case study for transom immersion ratio 0.8 and 1.0 at Froude number 0.6

\subsection{The case study using KCS hull form}

The total resistance at various transom immersion ratios was computed using similar grid configurations for all four variations of transom immersion on the KCS hull form. The resistance of each of the KCS hull form was computed at Froude numbers $0.195,0.23,0.26$ and 0.28 . The results are presented In Fig. 19 as the total resistance, $R_{T}$ with respect to the Froude number $F_{R}$. The KCS hull with the transom immersion ratio of 0.05 has a lower total resistance compared to the hull with transom immersion ratios of $0.1,0.15$ and 0.3 . The NPL hull with transom immersion ratio of 0.3 has the highest total resistance at all ranges of Froude number. The results were also compared in terms of its total resistance coefficient, $C_{T}$ as shown in Fig. 20. In Fig. 20, the total resistance coefficients for various transom immersion ratios are plotted with respect to the Froude number. The KCS hull with the transom immersion ratio of 0.05 has a lower total resistance coefficient similar to total 
resistance. However, the coefficients decreases with the increase in Froude number up to Fr $=0.26$ after which it decreases gradually although the total resistance inceases with the increase in Froude number.

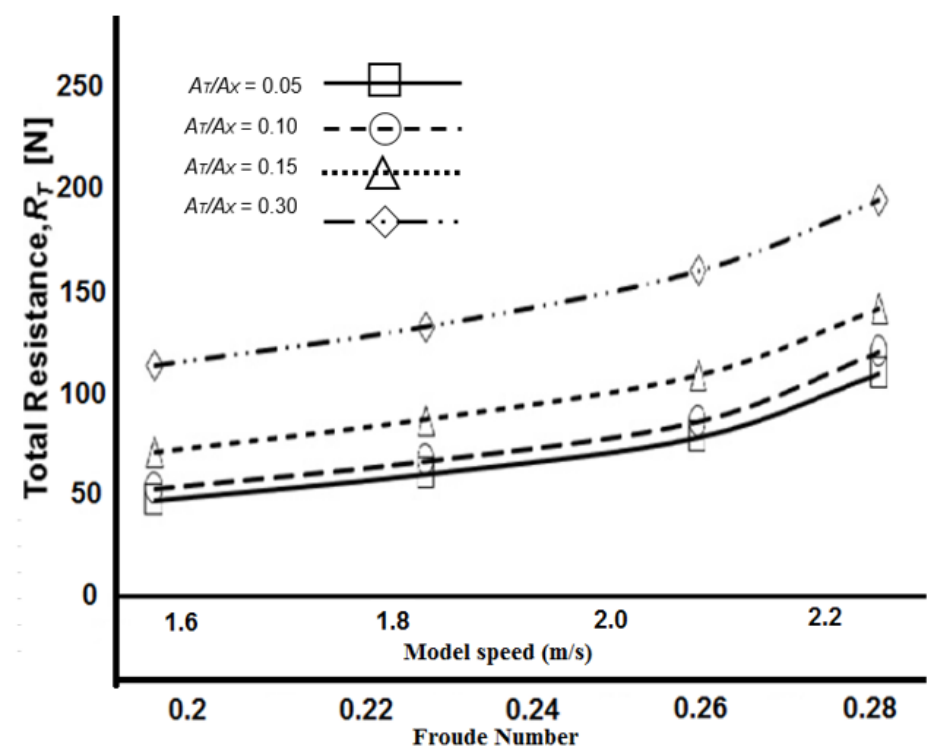

Fig. 19: The total resistance of the KCS hull at different transom immersion ratios.

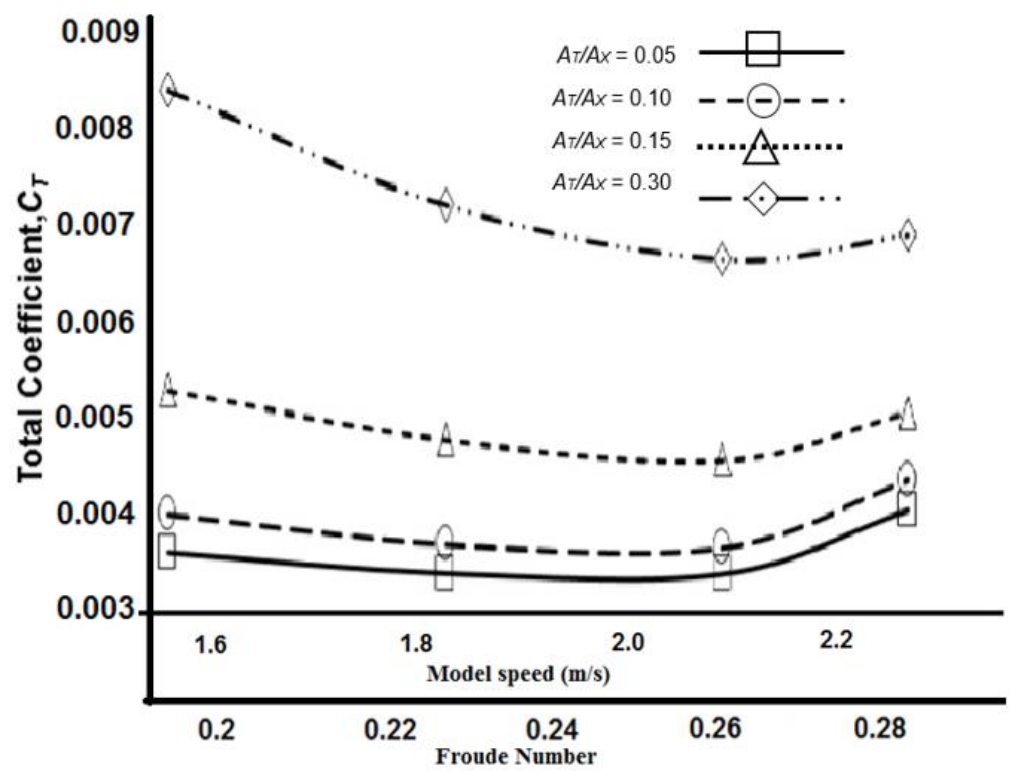

Fig. 20: The total resistance coefficient of the KCS hull at different transom immersion ratios

In Fig. 21, the wave resistance is compared at different transom immersion ratios. The KCS hull with the transom immersion ratios of 0.1 and 0.05 has a lower wave resistance coefficient when compared to the hull with transom immersion ratios of 0.15 and 0.3 . It appears that KCS hull with transom immersion 0.05 and 0.1 have the same wave resistance coefficient for all ranges of Froude number (0.195 - 0.28).

The wave-cut profiles were also compared in the case of KCS hull for all ranges of Froude number from 0.195 to 0.28 . All the wave-cut profiles were taken at $Y / L_{p p}=0.1$. It can be seen clearly in Figs. 22 and 23 at Froude number 0.195 and 0.23 respectively, the wave height $/ L_{P P}$ for the transom immersion ratio of 0.1 has the highest peak and the deepest trough compared to the wave height $/ L_{P P}$ for transom immersion ratios of $0.05,0.15$ and 0.3. Surprisingly, the wave-cut profiles for the transom immersion ratios of 0.15 and 0.3 have lower peak and shallower trough compared to the wave-cut profiles for transom immersion ratios of 0.05 and 0.1 . There is a significant increase in wave height at the stern region of the KCS hull with transom immersion ratios of 0.05 and 0.1 due to higher pressure gradient at the stern compared to the rest of the transom immersion ratios. 


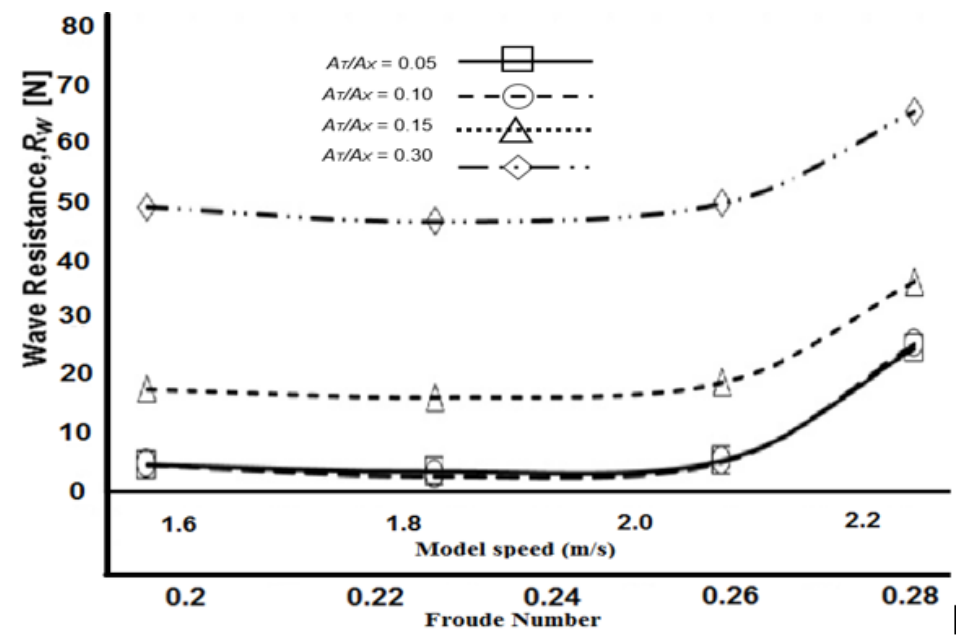

Fig. 21: The wave resistance of the KCS hull at different transom immersion ratios.

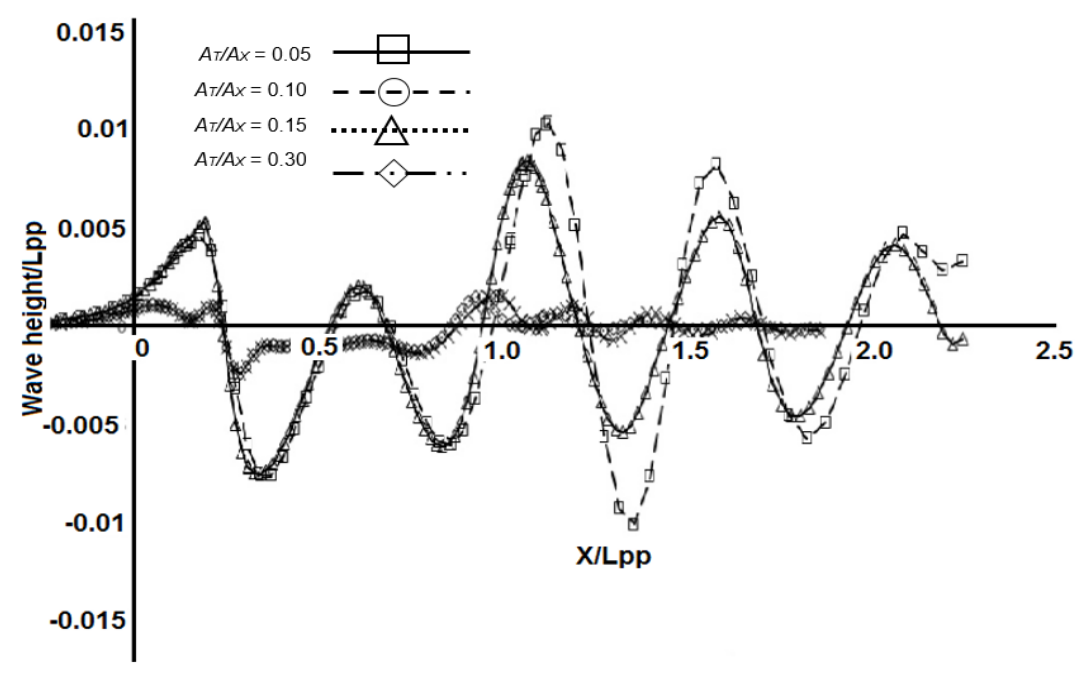

Fig. 22: The wave height/ $L_{P P}$ of the KCS hull at Froude number 0.195

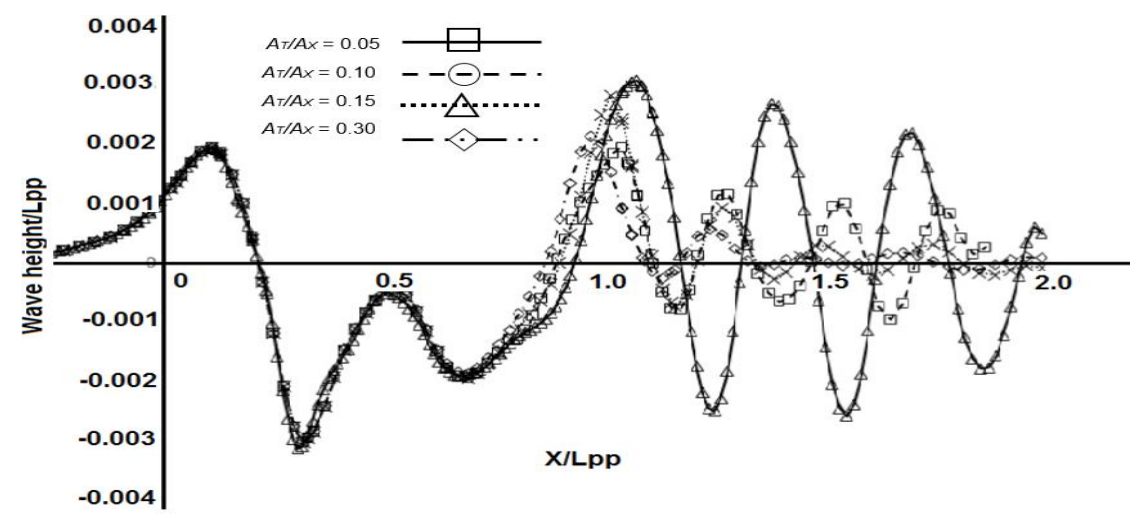

Fig. 23: The wave height/ $L_{P P}$ of the KCS hull at Froude number 0.23

It is seen in Fig. 24 that at Froude number 0.23 , the wave height $/ L_{P P}$ for the transom immersion ratio of 0.05 has the highest peak and the deepest trough when compared to the rest of the ratios. It appears that at this ratio of 0.05 , the stern wave system is more prominent compared to the transom immersion ratios of $0.1,0.15$ and 0.3 . Surprisingly at this speed, the wave-cut profile for transom immersion 0.3 appears to be the lowest compared to the rest of the transom immersion ratios. 


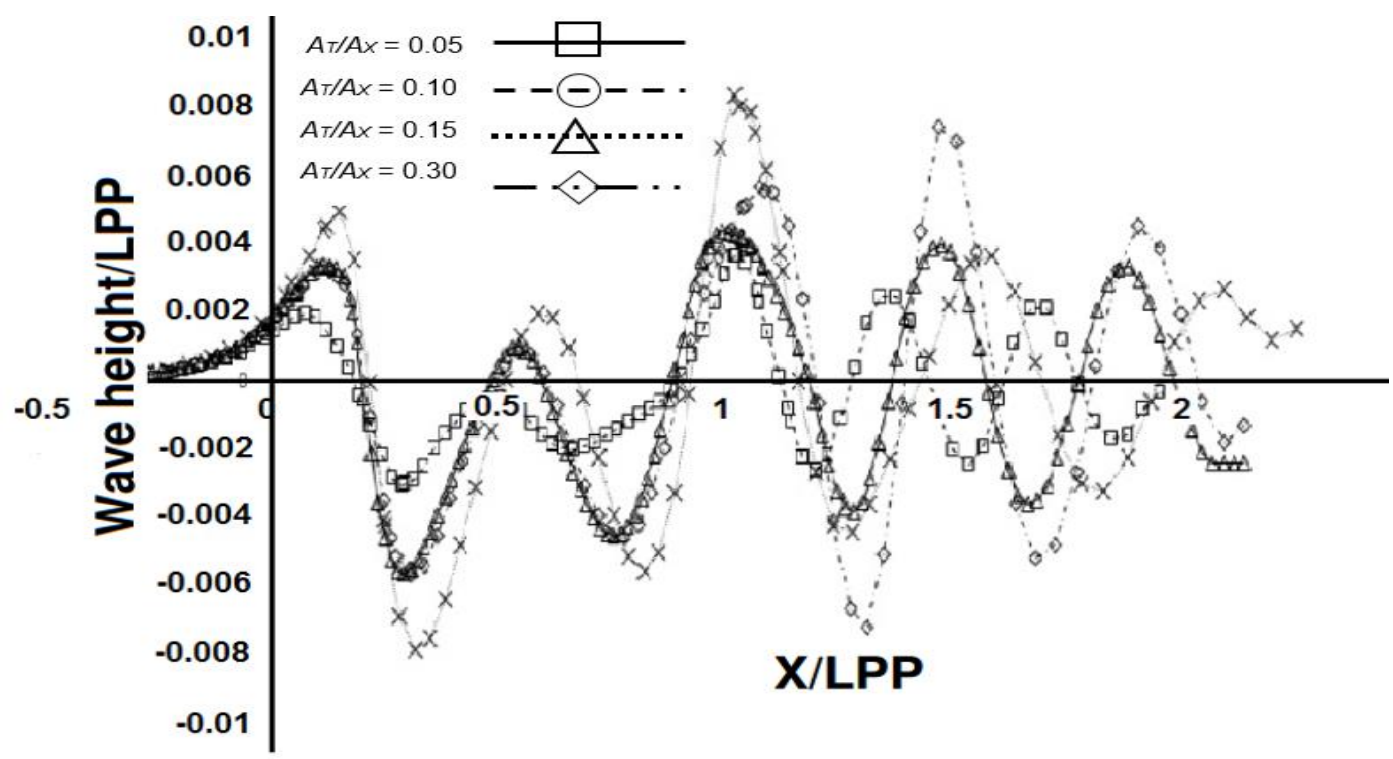

Fig. 24: The wave height/ $L_{P P}$ of the KCS hull at Froude number 0.26

It is observed from Fig. 25 that at Froude number 0.28, the wave height $/ L_{P P}$ for the transom immersion ratios of 0.1 and 0.15 have higher peak and deeper trough compared to the wave height $/ L_{P P}$ for transom immersion of 0.05 and 0.3. At this speed, the deeper transom immersion ratios of 0.1 and 0.15 produces a higher stern wave height than the shallower transom ratio of 0.05. Surprisingly again at this speed, the wave-cut profile for transom immersion 0.3 appears to be the lowest starting from the bow wave system to the stern wave system.

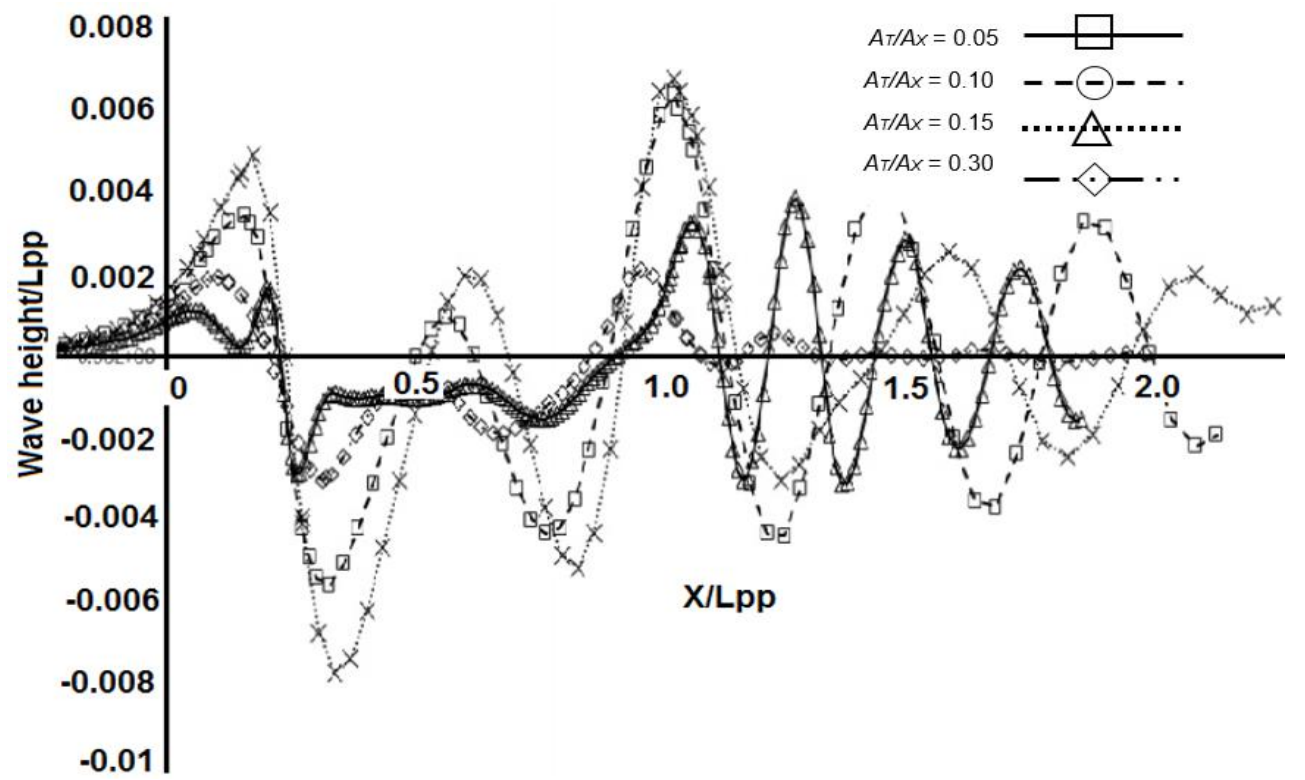

Fig. 25: The wave height/ $L_{P P}$ of the KCS hull at Froude number 0.28

The wave elevation for all transom immersion at Froude number 0.195 are shown in Figs. 26 and 27. It appears that the wave elevation is the highest at transom immersion ratio of 0.1 . It is clear that there is a high pressure gradient at the stern, producing a prominent stern wave system. 


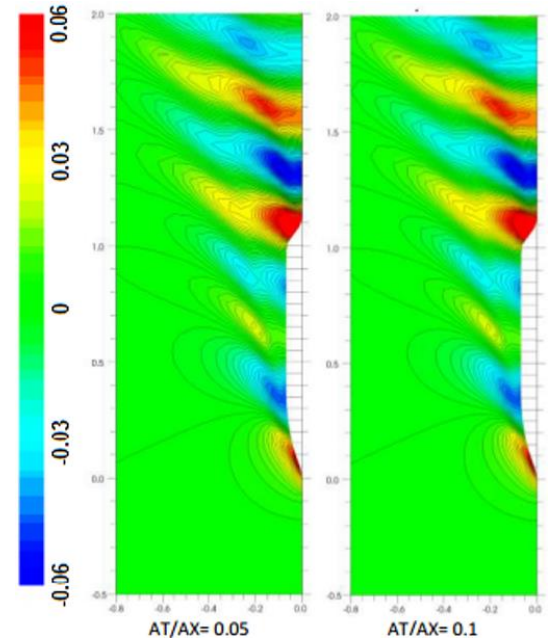

Fig. 26: The wave elevation contours for the KCS case study for transom immersion ratio 0.05 and at Froude number 0.195

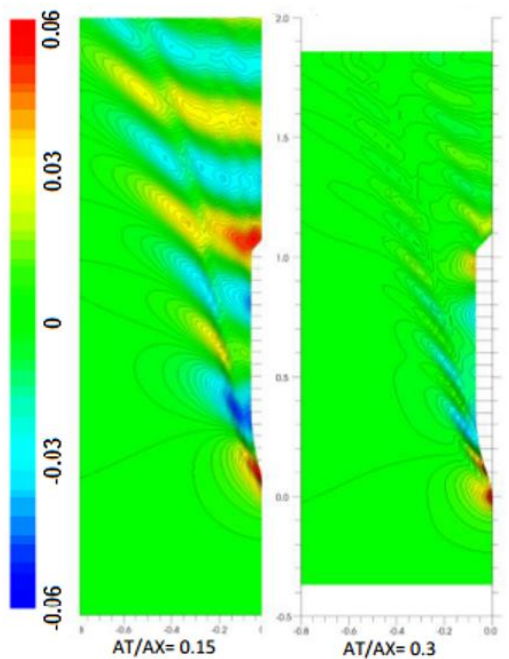

Fig. 27: The wave elevation contours for the KCS case study for transom immersion ratio 0.15 and 0.3 at Froude number 0.195

The wave elevation for all transom immersion at Froude number 0.23 are shown in Figs. 28 and 29. Surprisingly the KCS hull with transom immersion ratio of 0.05 produced a more prominent stern wave system compared to the rest of the KCS hull forms. The diagonal wavelength of the stern wave system also appears to be shorter compared to the wavelength for transom immersion ratios of 0.15 and 0.3. Figs. 30 and 31 shows the wave elevation for all transom immersion at Froude number 0.26. At this speed ratio, the KCS hull with transom immersion ratio of 0.15 and 0.3 produced a more prominent stern wave system compared to the rest of the KCS hull forms. In Figs. 32 and 33, the wave elevation for all transom immersion at Froude number 0.28 are shown. At this speed ratio, the stern wave system of the KCS hull with transom immersion of 0.1 seems to be more noticeable than the rest of the KCS hull forms.

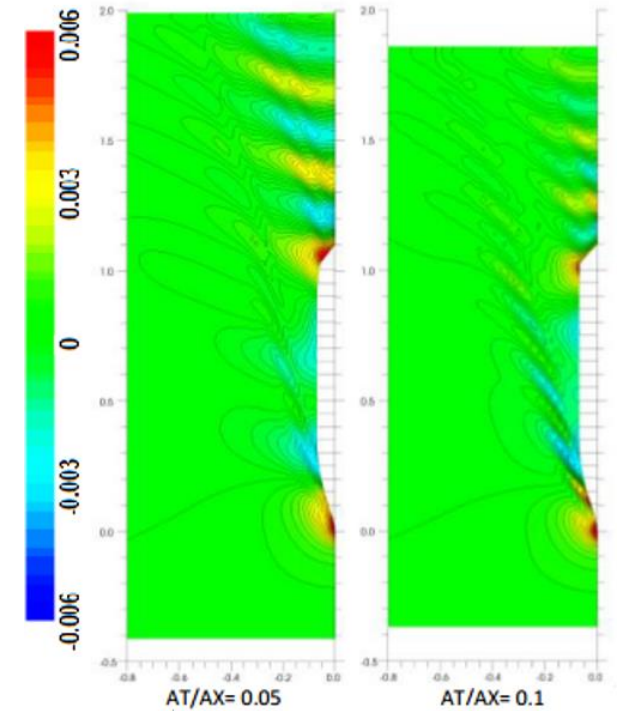

Fig. 28: The wave elevation contours for the KCS case study for transom immersion ratio 0.05 and 0.1 at Froude number 0.23

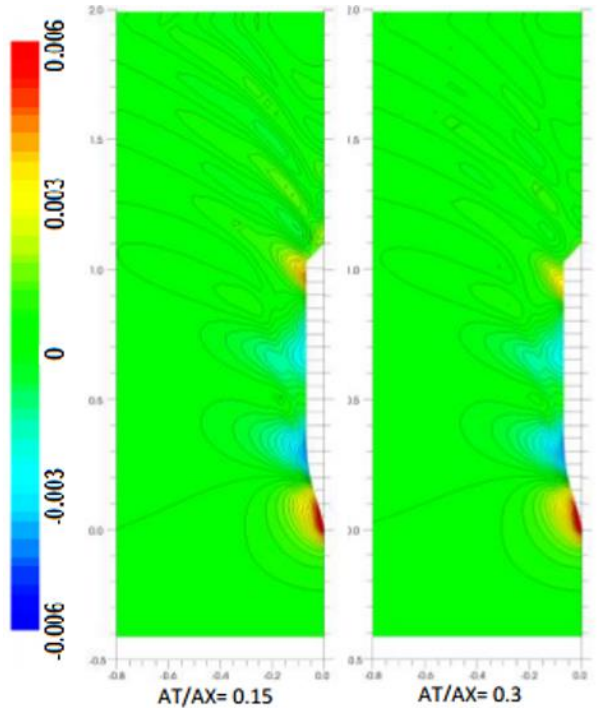

Fig. 29: The wave elevation contours for the KCS case study for transom immersion ratio 0.15 and 0.3 at Froude number 0.23 

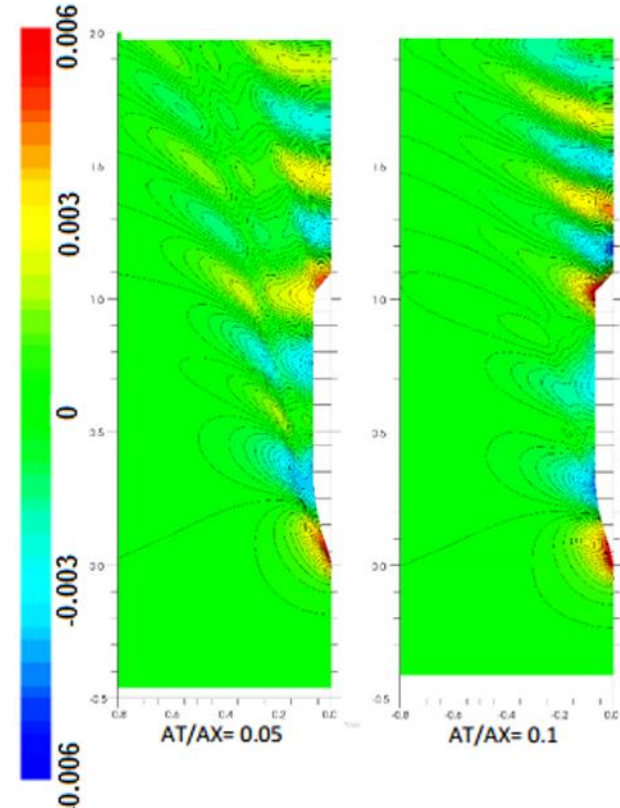

Fig. 30: The wave elevation contours for the KCS case study for transom immersion ratio 0.05 and 0.1 at Froude number 0.26

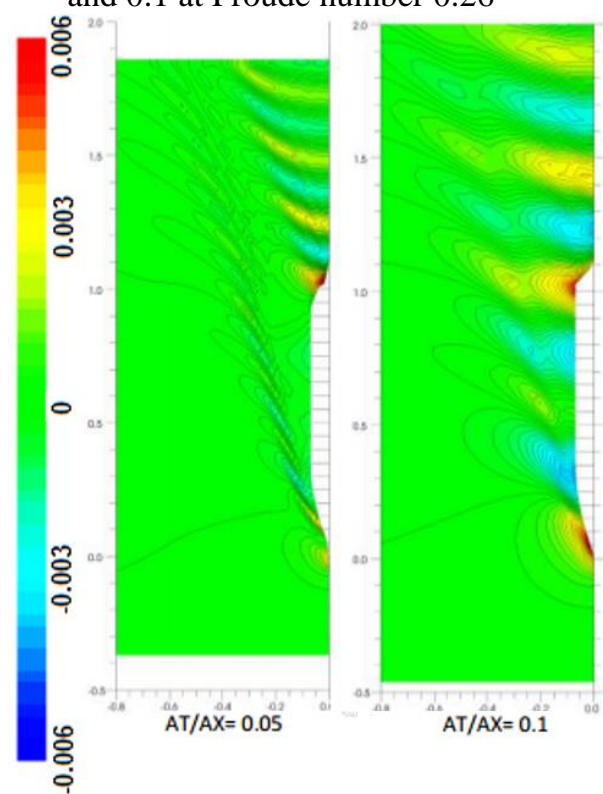

Fig. 32: The wave elevation contours for the KCS case study for transom immersion ratio 0.05 and 0.1 at Froude number 0.28

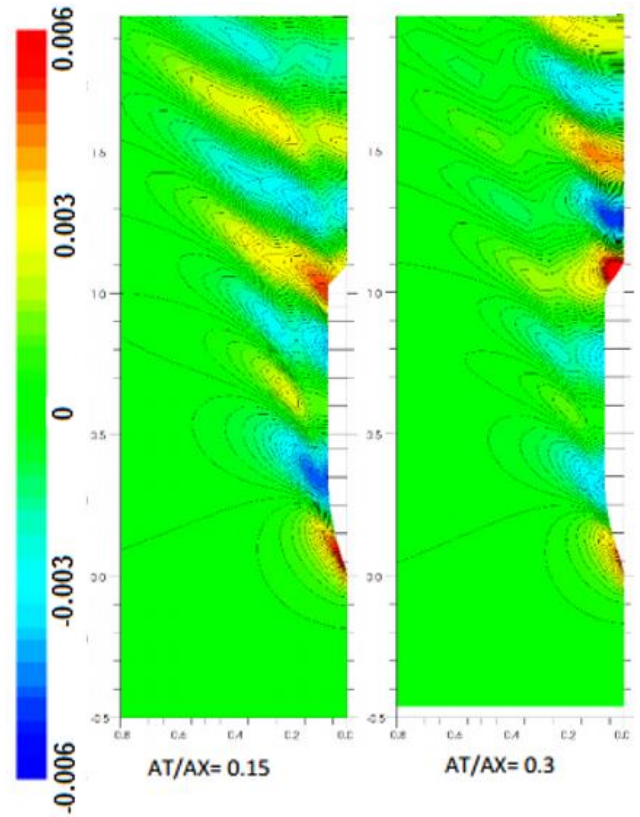

Fig. 31: The wave elevation contours for the KCS case study for transom immersion ratio 0.15 and 0.3 at Froude number 0.26

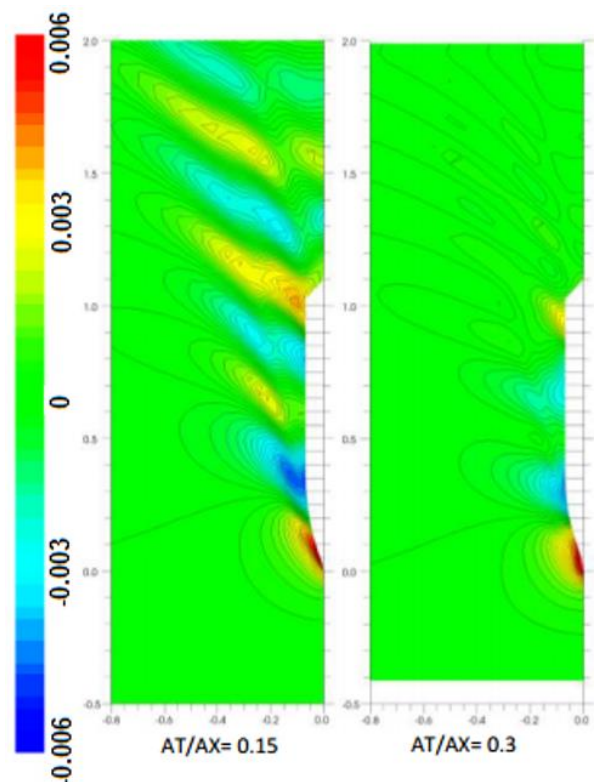

Fig. 33: The wave elevation contours for the KCS case study for transom immersion ratio 0.15 and 0.3 at Froude number 0.28

When referring to the plot of the resistance component as in Fig. 19, 20, and 21, it seems that the shallower transom seems to have the lowest resistance components. This could be true when the higher hydrodynamic pressure occurs at the stern creating a vertical lift. This vertical lift finally reduces the dynamic trim and sinkage, thus reducing the viscous resistance components due to smaller wetted surface area. It should be noted that these results of resistance components seem to contradict with the wave patterns results. The hull form with immersion ratio of 0.05 has the lowest resistance values but it does not have the lowest wave patterns. To check the limitation of the software used in this research, further investigation is required to check these results using other CFD software.

\section{Conclusions}


In this research, the influence of the transom immersion ratio of an NPL hull and a KCS hull on the total resistance, wave resistance and the wave profile were investigated. The resistance of the NPL hull and the KCS hull with varied transom immersion ratios was computed using a commercial CFD software, Shipflow 6.3.

It was found that the NPL hull with the transom immersion ratio of 1 has the highest total and wave resistance compared to the rest of the transom immersion ratios. The total resistance and the wave resistance coefficients for the transom immersion ratio of 1 were also to be found higher compared to the rest of the hull forms. The increased resistance is contributed by two main components which are frictional resistance and wave resistance. As the transom immersion ratio increases, the wetted surface area increases. This results in a higher frictional resistance. The increase in the transom immersion also creates a larger stern wave system.

In the case of KCS hull, the shallower transom seems to have the lowest resistance at all the speed ranges. But these results from the resistance components seem to contradict with the wave pattern results. In the case of hull form with a transom immersion ratio of 0.05 has the lowest resistance values but it does not have the lowest wave patterns. However further investigation is needed to verify some results on the wave elevation contour, where in some cases, the lower transom immersion ratio has a higher wave elevation contour than the higher transom immersion ratio.

\section{References}

Allroth, J. and Wu, T-H. (2013): A CFD investigation of sailing yacht transom sterns, Master Thesis, chalmers University if Technology, Sweden, pp.10.

Bailey, D. (1976): The NPL high speed round bilge displacement hull series, The Royal Institute of Naval Architect, London.

Broberg, L., Regnstrom, B. and Ostberg, M. (2007): XCHAP - Theoritical Manual, FLOWTECH International $\mathrm{AB}$, Sweden.

Broberg, L. and Orych, M. (2019): Shipflow 6.5 - Users Manual, FLOWTECH International AB, Sweden. Doctors, L. J., Macfarlane, G. J. and Richard, Young. (2007): A study of transom-stern ventilation, International Shipbuilding Progress 54,vol. 2, pp. 145-163.

Dea, J. O.', Jenkins, D. and Nagle, T. (1981): Flow characteristics if a transom stern ship, Technical Report, David Taylor Ship Research and Development.

Duy, T-N., Hino, T. and Suzuki, K. (2017): Numerical study on stern flow fields of ship hulls with different transom configurations, Ocean Engineering, Vol. 129, pp. 401-414.

https://doi.org/10.1016/j.oceaneng.2016.10.052

Eslamdoost, A., Larsson, L., and Bensow, R. (2015): On transom clearance, Ocean Engineering, Volume 99, pp. 55-62. https://doi.org/10.1016/j.oceaneng.2015.02.008

Fujisawa, J., Ukon, Y., Kume, K. and Takeshi, H. (2000): Local velocity field measurements around kcs model (SRI M.S.No.631) in the SRI 400m towing tank, Ship Performance Division Report No.00-003-02, The Ship Research Institute of Japan, Japan.

Haase, M., Binns, J. R., Thomas, G. and Bose, N. (2016): Wave-piercing catamaran transom stern ventilation process, Ship Technology Research, vol. 63(2), pp. 71-80. https://doi.org/10.1080/09377255.2015.1119922

Karim, M. M. and Naz, N. (2019): Numerical study on flow around modern ship hulls with rudder-propeller interaction, Journal of Marine Science and Application (JMSA), Springer, Vol.18, Issue 4, pp. 400 - 416.

https://doi.org/10.1007/s11804-019-00113-6

Kiss, T. K. and Compton, R. H. (1989): The Effects of transom geometry on the resistance of large surface combatants, Transactions SNAME, pp. 97. https://doi.org/10.21236/ADA200407

Larsson, L. and Raven, H. (2010): Ship Resistance and Flow, Principles of Naval Architecture Series, SNAME, USA, pp. 179.

Maki, K. J. (2005): Transom stern hydrodynamics, PhD thesis, University of Michigan.

Mustaffa Kamal, I. (2016): The powering performances of large waterjet and propeller driven catamarans at medium-speed, PhD thesis, Australian Maritime College, University of Tasmania, pp. 91 - 94.

Orych, M. and Larsson, L .(2015): Hydrodynamic aspects of transom stern optimization, $5^{\text {th }}$ High Performance Yacht Design Conference, Auckland.

Sireli, E. M., Insel, M. and Goren, O. (2000): The effects of transom stern on the resistance of high speed craft, International Maritime Association of the Mediterranean (IMAM), Italy. 
Van, S. H., Kim, W. J., Kim, D. H., Yim, G.T., Lee, C. J. and Eom, J. Y. (1997): Measurements of flows around a 3600teu container ship model, Proceedings of the Annual Autumn Meeting, SNAK, Seoul, pp. 300304 (in Korean).

Yamano, T., Kusukoni, Y., Kurutani, F., Ogawa, T., Ikebuchi, T. and Funeno, I. (2003): Effect of transom stern bottom profile form on stern wave resistance: A consideration on the effect of real stern end immersion, Journal of the Kansai Society of Naval Architects, Vol. 2003, No. 240, pp. 11-19. https://dx.doi.org/10.14856/jksna.2003.11_2 